\title{
Genetic diversity of Bartonella taylorii and Bartonella grahamii strains
}

\author{
Dalytė Mardosaitė-Busaitienè, \\ Paulina Amšiejūtè, \\ Jana Radzijevskaja*,
}

Algimantas Paulauskas

Faculty of Natural Sciences, Vytautas Magnus University, 8 Vileikos St, Kaunas 44404, Lithuania
Bacterial strains are a characteristic feature of many bacterial pathogens, including the species of the genus Bartonella. These bacteria are associated with different vertebrate hosts and vectors and have been detected in North America, Australia, Asia, and Europe. This study presents molecular characterization of Bartonella strains circulating in wild rodents. B. taylorii and B. grahamii are detected with high prevalence in mice, voles, and rats. However, there is a lack of knowledge on the geographical distribution and genetic diversity of B. taylorii and B. grahamii strains in wild rodents. The objectives of this study were to characterize the genetic diversity of $B$. taylorii and B. grahamii strains by sequence analysis of the housekeeping gene $(r p o B)$ and the 16S-23S rRNA intergenic species region (ITS). Sequence analysis of $r p o B$ gene revealed the presence of 15 B. taylorii genotypes and four B. grahamii genotypes in mice and voles captured in Lithuania. Sequence analysis of the ITS region revealed the presence of six $B$. taylorii genotypes and four $B$. grahamii genotypes in Lithuanian voles and mice. Analysis of genetic diversity demonstrated that $B$. grahamii strains derived from the same geographic region or from regions of close proximity more conservative, while B. grahamii strains from more distant areas are more variable. Genetic diversity of $B$. taylorii strains seems not to depend on geographic distance.

Keywords: genetic diversity, Bartonella grahamii, Bartonella taylorii, rodents, geographic distance

\section{INTRODUCTION}

Bacterial strains are a characteristic feature of many bacterial pathogens, including the species of the genus Bartonella. Bartonella are facultative intracellular, gram-negative bacteria that are transmitted to animals and humans by vectors such as fleas, mites, sand fleas and ticks (Birtles, Raoult, 1996; Kosoy et al., 2010). These bacte-

\footnotetext{
*Corresponding author. Email: jana.radzijevskaja@vdu.lt
}

ria have been detected in Asia, Australia, North America, and Europe (Vijay et al., 2012). Rodents play an important role as potential reservoirs of many infections caused by Bartonella pathogens such as Carrion's disease, endocarditis, fever, neuroretinitis, bacteremia, and others that have been reported worldwide (Okaro et al., 2017). Bartonella genus has one of the lowest recombination rates among intracellular bacteria. However, recombination events among Bartonella strains circulating within rodents occurred more frequently 
compared to human- and cat-adapted species, suggesting a broader host range for rodentadapted species (Buffet et al., 2013). More than one of genetic variants of bacteria could circulate in the same rodent species (Gutierrez et al., 2015; Morick et al., 2011).

Bartonella taylorii and Bartonella grahamii are often found in wild rodents from Muridae and Cricetidae families (Okaro et al., 2017). B. grahamii infects many species of mice and voles and can be pathogenic for humans. The pathogenic potential of $B$. taylorii is yet unknown (Kevin et al., 2004). In Europe, B. taylorii and $B$. grahamii detected in the yellow-necked mouse (Apodemus flavicollis), wood mouse (Apodemus sylvaticus), striped field mouse (Apodemus agrarius), herb field mouse (Apodemus uralensis), steppe field mouse (Apodemus witherbyi), harvest mouse (Micromys minutus), common house mouse (Mus musculus), bank vole (Myodes glareolus), common vole (Microtus arvalis), field vole (Microtus agrestis), root vole (Microtus oeconomus), and brown rat (Rattus norvegicus) (Špitalska et al., 2017; Gutierrez et al., 2015; Tołkacz et al., 2018; Obiegala et al., 2019). However, there is a lack of knowledge on the geographical distribution and genetic diversity of B. taylorii and B. grahamii strains in wild rodents.
The aim of this study was to investigate the genetic diversity of B. taylorii and B. grahamii strains in different species of rodents collected in Lithuania and compared with those submitted to GenBank based on the $r p o B$ gene and the 16S$23 \mathrm{~S}$ rRNA intergenic species region (ITS).

\section{MATERIALS AND METHODS}

In the present study, Bartonella DNA was collected form 30 Bartonella-infected rodents (trapped in different locations in Lithuania) representing seven species Apodemus flavicollis, Apodemus agrarius, Micromys minutus, Myodes glareolus, Microtus oeconomus, Microtus agrestis, and Mus musculus) (Table 1). A 795 bp fragment of Bartonella RNA polymerase $\beta$-subunit $(r p o B)$ gene (Renestro et al., 2001) and 0.8$0.9 \mathrm{~kb}$ fragment of the 16S-23S rRNA gene intergenic species region (ITS) (Jensen et al., 2000; Kaewmongkol, 2012) were amplified by conventional and nested PCRs. The best quality PCR products were extracted from agarose gel and purified using GenJET PCR purification kit (Thermo Fisher Scientific, Lithuania) and were sent for sequencing (Macrogen Europe, Netherlands) after preparation.

Genetic polymorphism of B. grahamii and B. taylorii strains circulating in rodents from

Table 1. Distribution of $\boldsymbol{B}$. grahamii and $\boldsymbol{B}$. taylorii in rodents in Lithuania

\begin{tabular}{|c|c|c|c|}
\hline & species & Bartonella grahamii & Bartonella taylorii \\
\hline \multicolumn{2}{|c|}{ Yellow-necked mouse (Apodemus flavicollis) } & + & + \\
\hline \multicolumn{2}{|c|}{ Striped field mouse (Apodemus agrarius) } & + & + \\
\hline \multicolumn{2}{|c|}{ Harvest mouse (Micromys minutus) } & + & - \\
\hline \multicolumn{2}{|c|}{ Common house mouse (Mus musculus) } & + & - \\
\hline \multicolumn{2}{|c|}{ Bank vole (Myodes glareolus) } & + & + \\
\hline \multicolumn{2}{|c|}{ Root vole (Microtus oeconomus) } & + & + \\
\hline \multicolumn{2}{|c|}{ Field vole (Microtus agrestis) } & - & + \\
\hline \multicolumn{4}{|c|}{ Location } \\
\hline Rusnè & $55^{\circ} 19^{\prime} 26.23^{\prime \prime} \mathrm{N}, 21^{\circ} 20^{\prime} 24.15^{\prime \prime} \mathrm{E}$ & + & + \\
\hline Žalgiriai & $55^{\circ} 18^{\prime} 40.0^{\prime \prime} \mathrm{N}, 21^{\circ} 26^{\prime} 10.0^{\prime \prime} \mathrm{E}$ & - & + \\
\hline Beištrakiai & $54^{\circ} 54^{\prime} 22.3^{\prime \prime} \mathrm{N}, 24^{\circ} 20^{\prime} 28.6^{\prime \prime} \mathrm{E}$ & + & + \\
\hline Elektrènai & $54^{\circ} 45^{\prime} 37.22^{\prime \prime} \mathrm{N}, 24^{\circ} 40^{\prime} 41.45^{\prime \prime} \mathrm{E}$ & + & + \\
\hline Dubingiai & $55^{\circ} 03^{\prime} 38.1^{\prime \prime} \mathrm{N}, 25^{\circ} 27^{\prime} 03.7^{\prime \prime} \mathrm{E}$ & + & + \\
\hline Lukštas & $55^{\circ} 51^{\prime} 0.94^{\prime \prime} \mathrm{N}, 26^{\circ} 12^{\prime} 6.11^{\prime \prime} \mathrm{E}$ & + & + \\
\hline
\end{tabular}

+, Bartonella-infection present; -, Bartonella infection absent. 
Lithuania and different parts of the world was analysed using the $r p o B$ gene and ITS region sequences obtained in this study and previously submitted in GenBank. Sequences were analyzed using Mega X software package, v10.0.5 (Kumar et al., 2018) and the NCBI BLAST $^{\circledast}$ software (http://blast.ncbi.nlm.nih. gov). Nucleotide diversity (п), haplotype diversity $(\mathrm{Hd})$, and the average number of nucleotide differences $(\mathrm{k})$ were calculated using DnaSP v5.10.01. Overall genetic distance (D), variable sites $(\mathrm{V})$ and parsimony-informative sites $(\mathrm{Pi})$ were calculated by using Mega X software, v10.0.5. (Librado, Rozas, 2009).

\section{RESULTS}

Genetic diversity of B. grahamii and B. taylorii strains

A total of 38 good-quality B. grahamii $(n=13)$ and B. taylorii $(n=25)$ rpoB gene and ITS re- gion sequences obtained in this study were included in genetic analysis.

Sequence analysis of eight $B$. grahamii rpoB gene sequences revealed the presence of four B. grahamii genotypes (with difference at seven nucleotides positions and three parsimony-informative sites): first genotype detected in $A$. agrarius, second genotype detected in A. agrarius, A. flavicollis, M. musculus and $M$. glareolus, the third genotype in $M$. glareolus, and the fourth genotype in A. agrarius and $M$. minutus. Three different genotypes were detected in A. agrarius (differed at five nucleotide positions) and two in M. glareolus (differed at three nucleotide positions) rodent species (Table 2a; 4a). Four B. grahamii genotypes were identified based on five B. grahamii ITS region sequences (analysed sequences differed at 15 nucleotides positions and have one parsimonyinformative site): the first genotype was detected in A. agrarius, the second in A. agrarius and

Table 2. Comparison of the rpoB gene (a.) and ITS (b.) region sequences of $B$. grahamii obtained from rodents in Lithuania

\begin{tabular}{|c|c|c|c|c|c|c|c|c|c|c|c|c|c|c|c|c|}
\hline $\begin{array}{l}\text { Genetic variant } \\
\text { a. }\end{array}$ & Rodent species & \multicolumn{15}{|c|}{ Nucleotide position } \\
\hline & & & & & & & \multicolumn{3}{|c|}{2} & \multicolumn{2}{|l|}{2} & \multicolumn{2}{|l|}{2} & \multicolumn{2}{|l|}{4} & 4 \\
\hline & & & & 4 & & 8 & & 3 & & 6 & & 9 & & 4 & & 4 \\
\hline & & & & 4 & & 6 & & 0 & & 3 & & 6 & & 4 & & 6 \\
\hline 1 & A. agrarius & & & $\mathrm{T}$ & & $\mathrm{A}$ & & G & & $\mathrm{C}$ & & $\mathrm{T}$ & & - & & - \\
\hline \multirow{4}{*}{2} & A. agrarius & & & $\mathrm{A}$ & & G & & $\mathrm{C}$ & & $\mathrm{G}$ & & $\mathrm{C}$ & & - & & - \\
\hline & A. flavicollis & & & $\mathrm{A}$ & & G & & $\mathrm{C}$ & & G & & $\mathrm{C}$ & & - & & - \\
\hline & M. musculus & & & $\mathrm{A}$ & & $G$ & & $\mathrm{C}$ & & $\mathrm{G}$ & & $\mathrm{C}$ & & A & & A \\
\hline & M. glareolus & & & $\mathrm{A}$ & & $\mathrm{G}$ & & $\mathrm{C}$ & & $\mathrm{G}$ & & $\mathrm{C}$ & & $\mathrm{A}$ & & A \\
\hline 3 & M. glareolus & & & . & & G & & $\mathrm{C}$ & & G & & $\mathrm{C}$ & & G & & G \\
\hline \multirow{2}{*}{4} & A. agrarius & & & $\mathrm{A}$ & & G & & $\mathrm{C}$ & & G & & $\mathrm{C}$ & & G & & G \\
\hline & M. minutus & & & $\mathrm{A}$ & & G & & $\mathrm{C}$ & & G & & $\mathrm{C}$ & & G & & G \\
\hline \multicolumn{17}{|l|}{ b. } \\
\hline & & & & & & & 1 & 2 & 3 & 3 & 4 & 6 & 7 & 7 & 7 & 7 \\
\hline & & & 1 & 2 & 2 & 9 & 0 & 5 & 3 & 4 & 1 & 7 & 6 & 7 & 8 & 8 \\
\hline & & 9 & 2 & 1 & 9 & 7 & 0 & 5 & 5 & 3 & 1 & 5 & 7 & 0 & 0 & 2 \\
\hline 1 & A. agrarius & $\mathrm{C}$ & $\mathrm{T}$ & $\mathrm{C}$ & $\mathrm{A}$ & $\mathrm{A}$ & $\mathrm{A}$ & A & $\mathrm{T}$ & $\mathrm{C}$ & $\mathrm{C}$ & $\mathrm{G}$ & $\mathrm{A}$ & $\mathrm{G}$ & $\mathrm{A}$ & $\mathrm{C}$ \\
\hline \multirow{2}{*}{2} & M. glareolus & . & . & . & . & . & . & . & . & . & . & $\mathrm{T}$ & $\mathrm{G}$ & . & . & . \\
\hline & A. agrarius & . & . & . & . & . & . & . & . & . & . & $\mathrm{T}$ & G & . & . & . \\
\hline 3 & M. oeconomus & $\mathrm{T}$ & $\mathrm{C}$ & $\mathrm{T}$ & $G$ & $\mathrm{~T}$ & $\mathrm{G}$ & G & A & $\mathrm{T}$ & $\mathrm{T}$ & . & $\mathrm{G}$ & A & $\mathrm{T}$ & $\mathrm{T}$ \\
\hline 4 & M. minutus & $\cdot$ & . & . & . & $\cdot$ & . & $\cdot$ & . & . & . & . & $\mathrm{G}$ & . & . & . \\
\hline
\end{tabular}




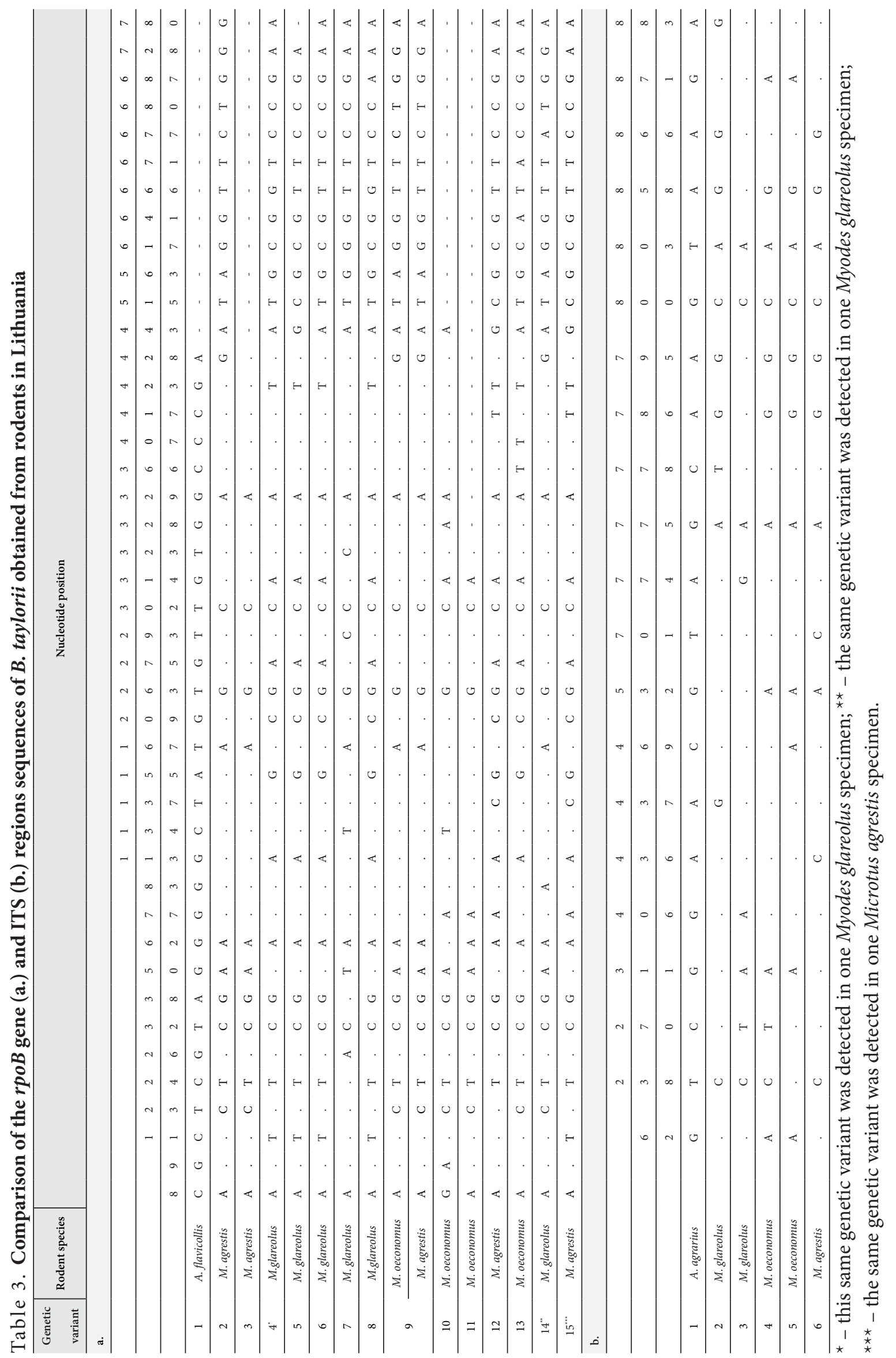


M. glareolus, the third in M. oeconomus, and the fourth genotype in $M$. minutus. Two different genotypes were detected in A. agrarius (sequences differed at two nucleotide positions) (Table 2b; 4a).

Sequence analysis of 19 B. taylorii rpoB gene sequences revealed the presence of $15 B$. taylorii genotypes (with difference at 43 nucleotide positions and 27 parsimony-informative sites): six different genotypes were detected in M. glareolus (differed at 27 nucleotide positions), five in $M$. agrestis (differed at 21 nucleotide positions), and four in M. oeconomus (differed at $23 \mathrm{nu}-$ cleotide positions). One genetic variant was detected in A. flavicollis specimen. M. agrestis and $M$. oeconomus and shared the same genotype (Table 3a; $4 a)$. Six B. taylorii genotypes were identified based on six ITS region sequences (analysed sequences differed at 21 nucleotides positions and have ten parsimony-informative sites): two different genotypes were detected in $M$. glareolus (differed at 11 nucleotide positions) and two in M. oeconomus (differed at three nucleotide positions). Different genotypes were detected in $M$. agrestis and $A$. agrarius (Table $3 \mathrm{~b} ; 4 \mathrm{a}$ ).

B. taylorii strains isolated from rodents in Lithuania demonstrated a higher genetic diversity based on estimated parameters of haplotype diversity (Hd), nucleotide diversity ( $\Pi$ ), the average number of nucleotide differences (k) compared with $B$. grahamii strains (Table 4a). $B$. grahamii strains demonstrated higher similarity to each other compared with $B$. taylorii strains (overall mean genetic distance (D) was higher for B. taylorii) (Table 4a).

In this study, we also used GenBank sequences of rodents from France, China, Russia, South Korea, Japan, USA, Canada, UK, Germany, and Slovakia to analyse genetic diversity of B. grahamii and B. taylorii strains (Table $4 \mathrm{~b}$ ). Among analysed sequences of both genetic regions, the higher number of genotypes was detected in B. taylorii, while haplotype diversity parameters were similar in both Bartonella species. The number of variable sites, parsimony-informative sites, nucleotide diversity, and the average number of nucleotide differences showed higher values for B. grahamii compared with those obtained for B. taylorii (Table $4 \mathrm{~b}$ ). The overall mean genetic distance among B. grahamii strains isolated from Lithuanian rodents was five times lower compared with the genetic distance estimated among B. grahamii strains from different geographical regions. Similar patterns were observed in values of nucleotide diversity (Table $4 a, b$ ).

Table 4. Comparison of genetic diversity and nucleotide polymorphism of the $r p o B$ gene and ITS region sequences of $B$. taylorii and $B$. grahamii between rodents from Lithuania (a) and rodents from Lithuania and other countries (b)

\begin{tabular}{|c|c|c|c|c|c|c|c|c|c|}
\hline $\begin{array}{l}\text { Bartonella spp. } \\
\quad \text { (sq nr.) }\end{array}$ & $\begin{array}{l}\text { Gene / } \\
\text { region }\end{array}$ & $\begin{array}{l}\text { Fragment } \\
\text { size (bp) }\end{array}$ & $\begin{array}{c}\text { Genotypes } \\
\text { number }\end{array}$ & $\mathrm{D}( \pm \mathrm{SD})$ & $\mathrm{V}$ & $\mathrm{Pi}$ & $\Pi( \pm \mathrm{SD})$ & $\mathrm{Hd}( \pm \mathrm{SD})$ & k \\
\hline \multicolumn{10}{|l|}{ a. } \\
\hline B. taylorii (19) & rpoB & 797 & 15 & $0.0190 \pm 0.0039$ & 43 & 27 & $0.02241 \pm 0.00262$ & $0.895 \pm 0.048$ & 7.32749 \\
\hline B. grahamii (8) & rров & 797 & 4 & $0.0047 \pm 0.0019$ & 7 & 3 & $0.00454 \pm 0.00265$ & $0.464 \pm 0.020$ & 1.42857 \\
\hline B. taylorii (6) & ITS & 792 & 6 & $0.0117 \pm 0.0026$ & 21 & 10 & $0.01153 \pm 0.00149$ & $1.000 \pm 0.096$ & 9.13333 \\
\hline B. grahamii (5) & ITS & 754 & 4 & $0.0083 \pm 0.0028$ & 15 & 1 & $0.00823 \pm 0.00402$ & $0.900 \pm 0.161$ & 6.20000 \\
\hline \multicolumn{10}{|l|}{ b. } \\
\hline B. taylorii (31) & $r p o B$ & 797 & 23 & $0.019 \pm 0.003$ & 61 & 39 & $0.02334 \pm 0.00189$ & $0.929 \pm 0.029$ & 7.63226 \\
\hline B. grahamii (26) & $r p o B$ & 797 & 18 & $0.024 \pm 0.004$ & 76 & 41 & $0.02696 \pm 0.00350$ & $0.929 \pm 0.035$ & 8.49231 \\
\hline B. taylorii (19) & ITS & 812 & 19 & $0.021 \pm 0.003$ & 67 & 26 & $0.02196 \pm 0.00199$ & $0.988 \pm 0.021$ & 4.65497 \\
\hline B. grahamii (16) & ITS & 760 & 12 & $0.042 \pm 0.009$ & 59 & 40 & $0.03855 \pm 0.00340$ & $0.867 \pm 0.079$ & 15.1500 \\
\hline
\end{tabular}

Abbreviations: D, genetic distance; V, variable sites; Pi, parsimony-informative sites; $\Pi$, nucleotide diversity; Hd, haplotype diversity; $\mathrm{k}$, average number of nucleotide differences; SD, standard deviation; sq nr, sequences number. 


\section{DISCUSSION}

In Lithuania, B. taylorii strains isolated from rodents demonstrated a high genetic diversity and were frequently found in Myodes and Microtus voles. Bartonella isolates belonging to the $B$. grahamii genetic group were detected more frequently in Apodemus mice compared with voles. $B$. taylorii showed higher prevalence among Lithuanian rodents than $B$. grahamii. Similar results were obtained in Slovakia, where B. taylorii was most common among captured wild rodents: $85 \%$ of sequences were ascribable to B. taylorii and detected in A. flavicollis, $M$. glareolus, $M$. arvalis, and T. europaea, only four sequences derived from $A$. flavicollis and M. glareolus were found to be similar to B. grahamii (Špitalska et al., 2017). In Austria, B. taylorii was the most frequently detected species without apparent host specificity, B. grahamii was found only in wood mice (Schmidt et al., 2014). In France, as in Lithuania, B. taylorii identified in bank voles, field voles, and wood mice with a much higher prevalence than B. grahamii, which was recovered only in Myodes voles (Buffet et al., 2013).

In this study, B. grahamii strains were detected in 13 out of 38 rodent specimens and showed lower sequence diversity compared with $B$. taylorii. Sequence analysis of the $r p o B$ gene and ITS region revealed the presence of 15 and six B. taylorii genotypes, respectively. Only four B. grahamii genotypes were detected in voles and mice. In Europe, sequence analysis showed similar results. In France, where genetic analysis of B. taylorii and B. grahamii was performed, $B$. taylorii strains demonstrated a markedly higher genetic diversity than $B$. grahamii (Buffet et al., 2013). In contrast, research done in Heixiazi Island, China, showed different results. Genetic diversity estimated for B. grahamii was greater than the genetic diversity established for B. taylorii from the same area. It was suggested that all presently known isolates of B. grahamii from Apodemus spp. are split into two clades (one clade in Asia and another clade in Europe and North America). However, host species showed a more important role for the specificity of Bartonella genotypes than the geographic area distance (Li et al., 2015).

Similar results to ours were also observed in Sweden, where only three sequence types of $B$. grahamii were identified in four rodent species captured in three geographic locations separated by less than $30 \mathrm{~km}$. The study showed that environmental barriers in the form of water can lead to isolation and loss of genomic variability in host-associated bacterial populations and suggested that genetically similar strains can infect a range of different hosts (Berglund et al., 2010). In another research carried out in Sweden in 2003, Ehrenborg and colleagues could not find any association between B. grahamii subtype and infected host species. B. grahamii variants were separated by short geographic distances and the evidence of restricted gene flow was most discernible among populations separated by natural boundaries but not by species boundaries between the captured small mammals (Ehrenborg et al., 2003).

Analysis of genetic diversity demonstrated that B. grahamii strains derived from the same geographic region or from regions of close proximity are more conservative, while $B$. grahamii strains from more distant areas are more variable. Genetic diversity of $B$. taylorii strains seems not to depend on geographic distance (Table $4 a, b)$. The genotypic heterogeneity of these two bacteria species might be due to the several factors: the geographical distances, the environmental conditions, host animals, and specificity of vectors.

To better analyse the effects of geographical factors on Bartonella isolates, analysis of intra- and interspecies variations should be performed for more isolates of the same species of rodent hosts collected in different geographic locations. Since rodents live in a wide range of habitats that are frequented by humans and Bartonella species may be transmitted to humans by ticks, fleas, and lice (Jiypong et al., 2014), future surveys of the transmission and ecology of Bartonella are warranted in order to improve bartonellosis prevention. 


\section{ACKNOWLEDGEMENTS}

Research was partially funded by measure No. 09.3.3-LMT-K-712-03-0027 "Development of Competences of Scientists, Other Researchers, and Students through Practical Research Activities" of the European Structural Fund 2014-2020.

Received 30 May 2019 Accepted 30 June 2019

\section{References}

1. Berglund EC, Ehrenborg C, Pettersson OV, Granberg F, Näslund K, Holmberg M, Andersson SGE. Genome dynamics of Bartonella grahamii in micro-populations of woodland rodents. BMC Genomics. 2010; 11: 152.

2. Birtles RJ, Raoult D. Comparison of partial citrate synthase gene (gltA) sequences for phylogenetic analysis of Bartonella Species. Int J Syst Evol Microbiol. 1996; 4; 891-7.

3. Bown JK, Bennett M, Begon M. Flea-borne Bartonella grahamii and Bartonella taylorii in Bank Voles. Emerg Infect Dis. 2004; 10(4): 684-7.

4. Buffet JP, Marsot M, Vaumourin E, Gasqui P, Masséglia S, Marcheteau E, Huet D, Chapuis JL, Pisanu B, Ferquel E, Halos L, Vourc'h G, Vayssier-Taussat M. Co-infection of Borrelia afzelii and Bartonella spp. in bank voles from a suburban forest. Comp Immunol Microbiol Infect Dis. 2012; 35: 583-9.

5. Buffet JP, Kosoy M, Vayssier-Taussat M. Natural history of Bartonella-infecting rodents in light of new knowledge on genomics, diversity and evolution. Future Microbiol. 2013; 8: 1117-1128.

6. Ehrenborg C, Handley S, Ellis B, Mills J, Holmberg M. Bartonella grahamii infecting rodents display high genetic diversity over short geographic distances. Ann NY Acad Sci. 2003; 990: 233-5.
7. Gutierrez R, Krasnov B, Morich D, Gottlieb Y, Khokhlova IS, Harrus S. Bartonella infection in rodents and their flea ectoparasites: an overview. Vector Borne Zoonotic Dis. 2015; 15: 27-39.

8. Jensen WA, Fall MZ, Rooney J, Kordick DL, Breitschwerdt EB. Rapid identification and differentiation of Bartonella species using a single-step PCR Assay. J Clin Microbiol. 2000; 38: 1717-22.

9. Jiypong T, Jittapalapong S, Morand S, Rolain JM. Bartonella species in small mammals and their potential vectors in Asia. Asian Pac J Trop Biomed. 2014; 4: 757-67.

10. Kaewmongkol G. Detection and characterization of Bartonella species in Western Australia [PhD thesis]. School of Veterinary and Biomedical Sciences, Faculty of Health Sciences, Murdoch University, Perth, Western Australia. 2012.

11. Kosoy M, Bai Y, Sheff K, Morway C, Baggett H, Maloney SA, BoonmarvS, Bhengsri S, Dowell SF, Sitdhirasdr A, Lerdthusnee K, Richardson J, Peruski LF. Identification of Bartonella infections in febrile human patients from Thailand and their potential animal reservoirs. Am J Trop Med Hyg. 2010; 82: 1140-45.

12. Kumar S, Stecher G, Li M, Knyaz C, Tamura K. MEGA X: Molecular Evolutionary Genetics Analysis across computing platforms. Mol Biol Evol. 2018; 35: 1547-9.

13. Li D-M, Hou Y, Song X-P, Fu Y-Q, Li G-C, Li M, Eremeeva ME, Wu H-X, Pang B, Yue Y-J, Huang Y, Lu L, Wang J, Liu Q-Y. High prevalence and genetic heterogeneity of rodentborne Bartonella species on Heixiazi Island, China. Appl Environ Microbiol. 2015; 81: 7981-92.

14. Librado P, Rozas J. DnaSP v5: a software for comprehensive analysis of DNA polymorphism data. Bioinformatics. 2009; 25: 1451-2.

15. Morick D, Krasnov BR, Khokhlova IS, Gottlieb Y, Harrus S. Investigation of Bartonella acquisition and transmission in Xenopsylla 
ramesis fleas (Siphonaptera: Pulicidae). Mol Ecol. 2011; 20: 2864-70.

16. Obiegala A, Heuser E, Ryll R, Imholt C, Fürst J, Prautsch LM, Plenge-Bönig A, Ulrich RG, Pfeffer M. Norway and black rats in Europe: potential reservoirs for zoonotic arthropodborne pathogens? Pest Manag Sci. 2019; 75(6): 1556-63.

17. Okaro U, Addisu A, Casanas B, Anderson B. Bartonella species, an emerging cause of blood-culture-negative endocarditis. Clin Microbiol Rev. 2017; 30: 709-46.

18. Parte AC. LPSN - List of prokaryotic names with standing in nomenclature (bacterio.net), 20 years on. Int J Syst Evol Microbiol. 2018; 68: 1825-9.

19. Renesto P, Gouvernet J, Drancourt M, Roux V, Raoult D. Use of rpoB gene analysis for detection and identification of Bartonella species. J Clin Microbiol. 2001; 2: 430-437.

20. Schmidt S, Essbauer SS, Mayer-Scholl A, Poppert S, Schmidt-Chanasit J, Klempa B, Henning K, Schares G, Groschup MH, Spitzenberger F, Richter D, Heckel G, Ulrich RG. Multiple infections of rodents with zoonotic pathogens in Austria. Vector Borne Zoonot Dis. $2014 ;$ 14(7): 467-75.

21. Špitalska E, Minichová L, Kocianová E, Škultéty L, Mahríková L, Hamšíková Z, Slovák M, Kazimírová M. Diversity and prevalence of Bartonella species in small mammals from Slovakia, Central Europe. Parasitol Res. 2017; 116, 3087-95.

22. Tołkacz K, Alsarraf M, Kowalec M, DwużnikD, Grzybek M, Behnke JM, Bajer A. Bartonella infections in three species of Microtus: prevalence and genetic diversity, vertical transmission and the effect of concurrent Babesia microti infection on its success. Parasite Vector. 2018; 11: 491.
Dalytė Mardosaitė-Busaitienè, Paulina Amšiejūtè, Jana Radzijevskaja, Algimantas Paulauskas

\section{BARTONELLA TAYLORII IR BARTONELLA GRAHAMII PADERMIŲ GENETINE İ IVAIROVE்}

\section{Santrauka}

Skirtingų bakterijų padermès, ịskaitant ir Bartonella rūšis, gali būti susijusios su skirtingais stuburiniais šeimininkais bei vektoriais ir aptinkamos skirtinguose geografiniuose regionuose - Šiaurès Amerikos, Australijos, Azijos ir Europos. B. taylorii ir B. grahamii rūšies bakterijos dažnai identifikuojamos pelèse, pelènuose ir žiurkèse, tačiau vis dar trūksta žinių apie šių bakterijų padermių geografinị pasiskirstymą ir genetinę ìvairovę. Šio tyrimo tikslas buvo nustatyti B. taylorii ir B. grahamii padermiuc genetinę ịvairovę pagal $r p o B$ geno ir $16 \mathrm{~S}-23 \mathrm{~S}$ rRNR vidinio transkribuojančio regiono (ITS) sekas. Atlikus Lietuvoje sugautų pelènų ir pelių $r p o B$ geno sekų analizę, buvo nustatyta penkiolika B. taylorii ir keturi B. grahamii genotipai; ITS regiono sekų analizès metu nustatyti šeši $B$. taylorii ir keturi $B$. grahamii genotipai. Genetinès ịvairovès analizè rodo, kad B. grahamii padermès, kilusios iš to paties geografinio regiono ar nedideliu atstumu nutolusių vietovių, yra gana konservatyvios, o B. grahamii padermès, kilusios iš labai nutolusių vietovių, pasižymi didesne sekų ívairove. Geografinis atstumas B. taylorii padermių genetinei ịvairovei ittakos neturi.

Raktažodžiai: genetinè ịvairovė, Bartonella grahamii, Bartonella taylorii, graužikai, geografinis atstumas 